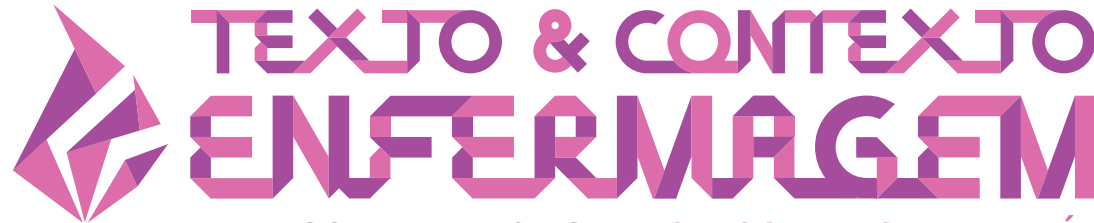

TEXT \& CONTEXT NURSING TEXTO \& CONTEXTO ENFERMERÍA

\section{EXPOSURE TO TOXIC AGROCHEMICALS AND DEVELOPMENT OF CONGENITAL MALFORMATIONS: A SCOPING REVIEW}

\section{Nathalia Zorzo Costa ${ }^{1}$ Carlise Rigon Dalla Nora ${ }^{2}$ (1) Lucia Helena Donini Souto ${ }^{3}$ (1) Franciela Delazeri Carlotto ${ }^{3}$ (1) Richard dos Santos Afonso ${ }^{4}$ (1) Deise Lisboa Riquinho² (1)}

${ }^{1}$ Universidade Federal do Rio Grande do Sul, Programa de Pós-graduação em Enfermagem. Porto Alegre, Rio Grande do Sul, Brasil. ${ }^{2}$ Universidade Federal do Rio Grande do Sul, Escola de Enfermagem. Departamento de Assistência e Orientação Profissional. Porto Alegre, Rio Grande do Sul, Brasil. ${ }^{3}$ Grupo Hospitalar Conceição. Porto Alegre, Rio Grande do Sul, Brasil. ${ }^{4}$ Universidade Federal do Rio Grande do Sul, Instituto de Geociências. Porto Alegre, Rio Grande do Sul, Brasil.

\begin{abstract}
Objective: to assess whether maternal and paternal exposure to toxic agrochemicals throughout life causes congenital malformations.

Method: a scoping review was carried out on the PUBMED, CINAHL, EBSCO, MEDLINE, LILACS, SciELO, BDENF, Web of Science and ATHENA databases between August and September 2019 and updated in December 2020. A cohort and case control study were included, which addressed the effects of parents' exposure throughout their lives to toxic agrochemicals which caused congenital malformation outcomes.

Results: the review covered 32 studies published between 2005 and 2020. The main malformations presented are related to the reproductive system, nervous system, musculoskeletal system, transverse limb deficiencies, digestive system and other malformations such as fetal growth restrictions, cleft palate and congenital heart disease. The most investigated toxic agrochemicals in the studies were the herbicides represented by atrazine. Conclusion: maternal and paternal exposure to toxic agrochemicals can be associated with greater chances of children being born with congenital malformations, especially those related to the male reproductive system.
\end{abstract}

DESCRIPTORS: Congenital, hereditary and neonatal diseases and anomalies. Toxic agrochemicals. Pesticides. Review. 


\section{EXPOSIÇÃO AOS AGROTÓXICOS E O DESENVOLVIMENTO DE MALFORMAÇÕES CONGÊNITAS: REVISÃO DE ESCOPO}

\section{RESUMO}

Objetivo: avaliar se a exposição materna e paterna aos agrotóxicos ao longo da sua vida causa malformação congênita.

Método: realizou-se uma revisão de escopo nas bases PUBMED, CINAHL, EBSCO, MEDLINE, LILACS, SciELO, BDENF, Web of Science e ATHENA entre agosto e setembro de 2019 e atualizadas em dezembro de 2020. Incluíram-se estudo de coorte e caso controle que abordaram os efeitos da exposição dos pais ao longo da sua vida aos agrotóxicos e ocasionaram desfechos de malformação congênitas.

Resultados: a revisão abrangeu 32 estudos publicados entre 2005 e 2020. As principais malformações apresentadas estão relacionadas ao aparelho reprodutor; sistema nervoso, sistema musculoesquelético, deficiências transversais dos membros, sistema digestório e outras malformações como as restrições do crescimento fetal, fenda palatina e doenças cardíacas congênitas. Os agrotóxicos mais investigados nos estudos foram os herbicidas representados pela atrazina.

Conclusão: a exposição materna e paterna a agrotóxicos pode estar associada a maiores chances do nascimento de crianças que apresentem malformações congênitas, principalmente às malformações relacionadas ao sistema reprodutor masculino.

DESCRITORES: Doenças e anormalidades congênitas, hereditárias e neonatais. Agrotóxicos. Pesticidas. Revisão.

\section{EXPOSICIÓN A AGROTÓXICOS Y DESARROLLO MALFORMACIONES CONGÉNITAS: REVISIÓN DE ALCANCE}

\section{RESUMEN}

Objetivo: evaluar si la exposición materna y paterna a los agrotóxicos a lo largo de la vida causa malformaciones congénitas.

Método: se realizó una revisión de alcance en las siguientes bases de datos: PUBMED, CINAHL, EBSCO, MEDLINE, LILACS, SciELO, BDENF, Web of Science y ATHENA, entre agosto y septiembre de 2019, actualizada en diciembre de 2020. Se incluyeron estudios de cohorte y de casos control que abordaban los efectos de la exposición a lo largo de la vida de los padres a agrotóxicos que ocasionaron resultados de malformaciones congénitas.

Resultados: la revisión abarcó 32 estudios publicados entre 2005 y 2020. Las principales malformaciones que se hicieron presentes están relacionadas al aparato reproductor, al sistema nervioso, al sistema musculoesquelético, a deficiencias transversales de las extremidades y al sistema digestivo, además de otras malformaciones como ser restricciones en el crecimiento fetal, fisura palatina y enfermedades cardíacas congénitas. Los agrotóxicos más investigados en los estudios fueron los herbicidas, representados por la atrazina.

Conclusión: la exposición materna y paterna a los agrotóxicos puede estar asociada a mayores probabilidades de que los hijos nazcan con malformaciones congénitas, principalmente las relacionadas a aparato reproductor masculino.

DESCRIPTORES: Enfermedades y anomalías congénitas, hereditarias y neonatales. Agrotóxicos. Pesticidas. Revisión. 


\section{INTRODUCTION}

Diverse scientific evidence indicates that the environment can be related to the occurrence of congenital malformations such as anomaly of the limbs, orofacial fissures and failure in male urogenital development, in addition to spontaneous abortions, which can be accentuated when the parents are exposed to toxic agrochemicals. These congenital malformations are included in the list of congenital anomalies that can be defined as structural or functional changes that occur during intrauterine life ${ }^{1-2}$. Nearly $50 \%$ of the congenital anomalies are not linked to a specific conditioning factor. However, there are known causes that can be related, such as socioeconomic, demographic and environmental factors, infections, genetic factors and maternal nutritional status ${ }^{3}$.

Although some of the active ingredients of the agrochemicals are classified as moderately or slightly toxic, based on their acute effects, it is necessary to consider that the chronic effects can occur in months, years or even decades after exposure, manifesting in several diseases, such as tumors, congenital malformations, and endocrine, neurological and mental disorders ${ }^{4}$. In the vast areas of monocultures, agrochemicals are sprayed by means of tractors and airplanes on the crops, affecting not only the "pests" in the plantations, but also the soil, surface water, air, rain and food, as well as workers, surrounding residents and animals ${ }^{5}$.

The Brazil is the largest consumer of toxic agrochemicals in the world ${ }^{5}$. Based on this problem, the objective of this study was to assess whether maternal and paternal exposure to toxic agrochemicals throughout the life causes congenital malformations. This research included 32 studies, the quality of the evidence was considered as level 4 , that is, with evidence from well-designed cohort and case control studies ${ }^{6}$. Among the papers selected in the research, there are 12 research studies carried out in the USA and 3 in Brazil, showing anomalies related to the reproductive system (hypospadias, cryptochidism and micropenis $)^{7-17}$, to the nervous system ${ }^{12,18-24}$ and other malformations ${ }^{25-35,36-38}$.

\section{METHOD}

A scoping review was carried out following the method recommended by the Joanna Briggs Institute ${ }^{39}$ according to the theoretical framework proposed by Arksey and O'Malley ${ }^{40}$. This type of research consists of an exploratory review aimed at mapping, in the scientific production, relevant studies in a given area, following the steps of the scoping review: 1. Identification of the research question; 2. Identification of relevant studies; 3. Selection of studies; 4 . Data extraction; and 5. Summary and reporting of results. 6 . The sixth consultation step, considered optional, was not used in this study ${ }^{39,41}$.

The research question for this study was elaborated according to the $\mathrm{PCC}^{39}$ mnemonic combination (P: Population - mother or father exposed to toxic agrochemicals; C: Concept - congenital malformation; C: Context - the world), with the following guiding question being established: Is maternal and paternal exposure to toxic agrochemicals throughout life associated with congenital malformations in children?

One of the data sources consulted was the Virtual Health Library, which included the following databases: International Literature in Health Science (MEDLINE), Literatura Latino-Americana e do Caribe em Ciências da Saúde (LILACS), Base de dados da Enfermagem (BDENF ), Cumulative Index to Nursing and Allied Health Literature (CINAHL). The searches for the publications indexed in the virtual libraries included: National Library of Medicine (PUBMED), EBSCO, Scientific Electronic Library Online (SciELO), Web of Science and Université Paris-Est Créteil Val de Marne (ATHENA. In order to guarantee research integrity, the researchers reviewed the reference lists of the selected articles to identify other possible relevant studies.

The following controlled terminology descriptors recommended by the Medical Subject Headings (MeSH) and/or the Health Sciences Descriptors (Descritores em Ciências da Saúde, DeCS) were 
selected: Congenital, Hereditary, and Neonatal Diseases and Abnormalities; Congenital diseases; Congenital malformations; Neonatal Diseases; Agrochemicals; Pesticides. All of these terms were searched for in their equivalences in Spanish, French and Portuguese. The search strategy used followed the definition of each corresponding database. The Boolean AND operator was used with the following combinations: "Congenital, Hereditary, and Neonatal Diseases and Abnormalities" AND Pesticides; Pesticides AND "congenital anomalies"; Pesticides AND "congenital malformations"; Pesticides AND "neonatal diseases"; "Congenital, Hereditary, and Neonatal Diseases and Abnormalities" AND Agrochemicals; Agrochemicals AND "congenital anomalies"; Agrochemicals AND "congenital malformations"; Agrochemicals AND "neonatal diseases". The searches were performed between August and September 2019 and updated in December 2020.

The refinement of the articles found was based on the eligibility criteria. The pre-established inclusion criteria were as follows: cohort and/or case control study, published in Portuguese, Spanish, English and French, which studied the effects of maternal and/or paternal exposure to toxic agrochemicals throughout life on congenital malformations. No time limit was established and duplicate studies, reviews, meta-analyses, theses, dissertations and books were excluded.

In addition to this, to systematize the process of inclusion of the studies, the PRISMA Extension for Scoping Reviews ${ }^{42}$ methodology was chosen. The studies were pre-selected from reading the titles and abstracts, and the final sample was reached based on reading the articles in full, according to the flowchart shown in Figure 1.

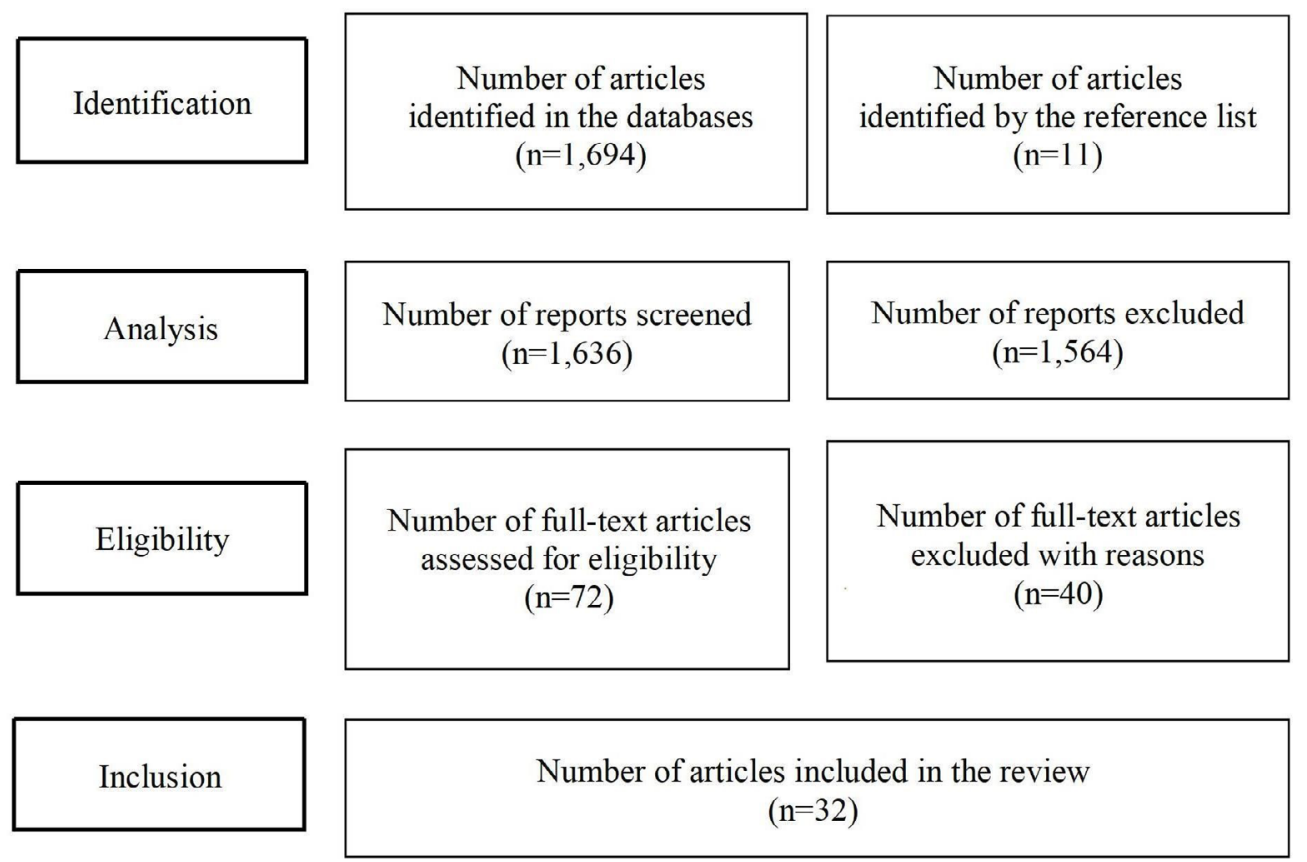

Figure 1 - Flowchart of the selection of studies that compose the research according to PRISMA ScR ${ }^{42}$

In the data extraction stage, an instrument structured in Microsoft Excel was used, which allowed mapping the essential elements of the studies, such as author, year of publication, country where the study was conducted, journal, type of study, description of the sample, outcome and the level of evidence of the study ${ }^{6}$. The data were extracted in a double-independent fashion and, in case of dissent, a third reviewer was contacted. In this way, in order to present an overview of the entire material, the presentation of the results was elaborated in a chart with the main characteristics of the studies, organizing a numerical description of the results and a thematic description according to the nature of the research. 


\section{RESULTS}

After the process of evaluation and selection of articles, 32 studies were included in the scoping review $^{7-38}$. These were published between 2005 and 2018 (Chart 1). The results were presented with a description of the characteristics of the studies, and the main congenital malformations evidenced from the selected studies and the most frequently identified toxic agrochemicals in the studies are described.

Chart 1 - Characterization of the articles according to author, year of publication, country where the study was conducted, type of study, sample, assessed outcome and level of evidence. Porto Alegre, RS, Brazil, 2020. $(n=32)$

\begin{tabular}{|c|c|c|c|c|}
\hline Country & Type of study & Description of the sample & Assessed outcome & $\begin{array}{l}\text { Evidence } \\
\text { level }\end{array}$ \\
\hline France $^{10}$ & cohort & 1,068 pregnant women & $\begin{array}{l}\text { Malformations of the } \\
\text { reproductive system }\end{array}$ & IV \\
\hline Brazil $^{8}$ & cohort & 2710 male born & $\begin{array}{l}\text { Cryptorchidism, } \\
\text { hypospadias and } \\
\text { micropenis }\end{array}$ & IV \\
\hline France $^{27}$ & cohort & 579 pregnant women & Fetal growth restriction & IV \\
\hline USA $^{19}$ & control case & 92 cases and 56 controls & Holoprosencephaly & IV \\
\hline USA $^{11}$ & control case & 165 cases and 165 controls & Cryptorchidism & IV \\
\hline USA $^{24}$ & control case & 291 cases for 2,745 controls & Spina bifida & IV \\
\hline USA $^{17}$ & control case & $\begin{array}{l}343 \text { cases of hypospadias and } \\
1,422 \text { male controls }\end{array}$ & Hypospadias & IV \\
\hline$U_{S A}^{29}$ & control case & 372 cases for 3,720 controls & Choanal atresia or stenosis & IV \\
\hline $\mathrm{USA}^{26}$ & control case & 871 cases and 2,857 controls & $\begin{array}{l}\text { Craniosynostosis, } \\
\text { gastroschisis, } \\
\text { diaphragmatic hernia } \\
\text { and transverse limb } \\
\text { deficiencies }\end{array}$ & IV \\
\hline$U_{S A}^{21}$ & control case & 502 cases and 2950 controls & Neural tube defects & IV \\
\hline USA $^{23}$ & control case & 367 cases and 785 controls & $\begin{array}{l}\text { Anencephaly, spina bifida } \\
\text { with and without cleft } \\
\text { palate }\end{array}$ & IV \\
\hline$U_{S A}^{32}$ & control case & 156 cases for 785 controls & Gastroschisis & IV \\
\hline USA $^{15}$ & control case & 646 cases and 1493 controls & Hypospadias & IV \\
\hline$U_{S A}^{7}$ & control case & 20 cases and 28 controls & Hypospadias & IV \\
\hline USA $^{33}$ & control case & $\begin{array}{l}4 \text { controls for one case, with } 805 \\
\text { cases for } 3,616 \text { controls }\end{array}$ & $\begin{array}{l}\text { Gastroschisis and } \\
\text { abdominal wall defects }\end{array}$ & IV \\
\hline Brazil $^{25}$ & control case & 219 cases for 862 controls & Congenital malformations & IV \\
\hline Brazil $^{38}$ & control case & 137 cases for 274 controls & $\begin{array}{l}<5 \text { years with congenital } \\
\text { malformations }\end{array}$ & IV \\
\hline $\begin{array}{l}\text { Brazil and } \\
\text { India } 20\end{array}$ & control case & $\begin{array}{l}35 \text { cases } 35 \text { controls (mother } \\
\text { and baby) }\end{array}$ & $\begin{array}{l}\text { Congenital anomaly due to } \\
\text { neural tube defects }\end{array}$ & IV \\
\hline India $^{16}$ & control case & $\begin{array}{l}80 \text { boys with hypospadias and } \\
120 \text { controls }\end{array}$ & Hypospadias & IV \\
\hline India ${ }^{31}$ & control case & $\begin{array}{l}\text { cases of fetal growth restriction: } \\
50 \text {; control: } 50\end{array}$ & Fetal growth restriction & IV \\
\hline
\end{tabular}


Chart 1 - Cont.

\begin{tabular}{|c|c|c|c|c|}
\hline Country & Type of study & Description of the sample & Assessed outcome & $\begin{array}{l}\text { Evidence } \\
\text { level }\end{array}$ \\
\hline France $^{14}$ & control case & $\begin{array}{l}225 \text { cases of hypospadias and } \\
225 \text { controls }\end{array}$ & Hypospadias & IV \\
\hline Netherlands ${ }^{36}$ & control case & 1174 cases and 5602 controls & Congenital heart diseases & IV \\
\hline Netherlands ${ }^{37}$ & control case & $\begin{array}{l}387 \text { cases were defined as } \\
\text { non-syndromic clefts, } 1,135 \\
\text { chromosomal and } 4,352 \\
\text { malformed non-chromosomal } \\
\text { controls }\end{array}$ & Cleft lip & IV \\
\hline Mexico ${ }^{13}$ & control case & $\begin{array}{l}\text { Mother-baby binomial } \\
\text { Newborns diagnosed with } \\
\text { cryptorchidism }(n=41) \text {. } \\
41 \text { controls with deciduous } \\
\text { testicles }\end{array}$ & Cryptorchidism & IV \\
\hline Mexico ${ }^{18}$ & control case & $\begin{array}{l}184 \text { case women and } 225 \text { control } \\
\text { women }\end{array}$ & Neural tube defects & IV \\
\hline Ethiopia ${ }^{35}$ & control case & 136 cases and 273 control & Congenital malformations & IV \\
\hline Hungary ${ }^{34}$ & control case & 2,263 cases and 6,789 controls & Congenital heart diseases & IV \\
\hline Paraguay ${ }^{30}$ & control case & 66 cases and 66 controls & Congenital malformations & IV \\
\hline Greece $^{12}$ & control case & $\begin{array}{l}29 \text { children with hypospadias and } \\
49 \text { fathers }\end{array}$ & Hypospadias & IV \\
\hline Egypt $^{28}$ & control case & $\begin{array}{l}242 \text { cases of congenital } \\
\text { malformations and } 270 \text { controls }\end{array}$ & Congenital malformations & IV \\
\hline China $^{22}$ & control case & $\begin{array}{l}80 \text { fetuses or newborns with } \\
\text { NTDs, while the controls were } 50 \\
\text { healthy newborns }\end{array}$ & $\begin{array}{l}\text { Neural tube defects } \\
\text { (NTDs) }\end{array}$ & \\
\hline Italy ${ }^{9}$ & control case & $\begin{array}{l}80 \text { mothers with babies with } \\
\text { hypospadias and } 80 \text { mothers } \\
\text { with healthy controls }\end{array}$ & Hypospadias & IV \\
\hline
\end{tabular}

\section{Description of the studies}

The largest number of publications was in the years $2014^{12,21,23-25,29,32}(n=7), 2020^{10-11,19,34-36}(n=6)$, $2011^{8,15,16,22,27-28}(n=6)$ and in $2010^{7,9,13,18,33}(n=5)$. As for the country where the studies were developed, most were from the United States ${ }^{7,11,15,17,19,21,23-24,26,29,32},(n=10)$ followed by studies in Brazil ${ }^{2,25,38},(n=3)$, France $^{10,14,27}(n=3)$, India ${ }^{20,31,16}(n=3)$ and Mexico ${ }^{13,18}(n=2)$ (Chart 1). For being an inclusion criterion, most of the studies were case-control studies ${ }^{7-8,10,26-38}(n=29)$ and only three studies were cohort ${ }^{8,10,27}$ $(n=3)$ (Chart 1). In the 32 studies, the quality of the evidence was considered level 4 , that is, with evidence from well-designed cohort and case control studies ${ }^{6}$.

Below are four categories generated to meet the study objective: malformations related to the reproductive system, in which the main malformation found was hypospadias, followed by cryptorchidism and micropenis; malformations related to the nervous system such as neural tube defects (anencephaly, spina bifida), cleft palate and other malformations, such as fetal growth, digestive and musculoskeletal system restrictions, such as gastroschisis, choanal stenosis, transverse limb defects, cleft palate were also found. A fourth category with the toxic agrochemicals most frequently identified in the studies was also established. 


\section{Malformations related to the reproductive system}

Among the 32 studies analyzed, twelve demonstrated an association between exposure to toxic agrochemicals and the occurrence of outcomes related to the reproductive system. Of these studies, hypospadias appeared more frequently $(n=8)^{7-9,12,14-17}$, followed by cryptorchidism $(n=3)^{8,11,13}$ and micropenis $(n=1)^{8}$. The association between prenatal exposure to organochlorines and the occurrence of cryptorchidism was found through a case-control study. In addition to this, organophosphate levels in serum lipids of mother with children with cryptorchidism were analyzed, as well as in a control group of mothers of children with descending testicles; and the newborns' umbilical cord blood samples were studied. The levels of organochlorine metabolites were found in greater amount among mothers of newborns with cryptorchidism than among mothers of children with testicular descent: OR=1.79, $95 \% \mathrm{Cl}(1.34-2.24)^{13}$.

According to a cohort study carried out in northeastern Brazil, the prevalence of newborns diagnosed with micropenis with maternal and paternal exposure to household pesticides was investigated. Exposure was assessed using a questionnaire, testosterone analysis and molecular gene analysis. Of the newborns monitored, 56 malformations were identified, with cryptorchidism $(n=23)$, hypospadias $(n=15)$ and micropenis $(n=18)$. Most of the parents of these newborns reported exposure to toxic agrochemicals during paid and unpaid work, with $80.36 \%$ of the mothers and $58.63 \%$ of the fathers. This study indicated that exposure to disruptors of the endocrine system before and during pregnancy indicates that fetal contamination can be a risk factor for the development of male external genital malformation ${ }^{8}$. In the case control study carried out in Ethiopia, women exposed to pesticides during pregnancy were twice as prone to having children with congenital malformations $(\mathrm{OR}=3.19 ; 95 \% \mathrm{Cl}=1.31,10.96)^{35}$.

In a study carried out to assess the association between consumption of atrazine in water and hypospadias through a population-based control case, exposure to atrazine was measured using a maternal questionnaire on water and drinking water consumption $(\mathrm{OR}=1.00 ; 95 \% \mathrm{Cl})$, estimating the total maternal consumption of atrazine $(\mathrm{OR}=1.02 ; 95 \% \mathrm{Cl})$. In this study, the association between hypospadias and daily maternal exposure to atrazine during the critical window of genitourinary development was weak or null ${ }^{17}$.

When associated with exposure to organophosphates and hypospadias, through the analysis of organophosphate metabolites in the blood and hair collected from children with hypospadias and their parents, it was verified that they had higher values than the general population, suggesting that exposure to organophosphate and organochlorine pesticides can be a potential risk factor for hypospadias ${ }^{12}$.

A study ${ }^{9}$ verified the association between maternal environmental exposures to endocrine disrupting toxic agrochemicals and the occurrence of births diagnosed with hypospadias. Through a control case, an association was verified between maternal exposure to a class of endocrine disrupters $(\mathrm{OR}=2.44 ; 95 \% \mathrm{Cl})$ and $(\mathrm{OR}=4.11 ; 95 \% \mathrm{Cl})$ for more than one class. The high plasma concentration of hexachlorobenzene $(\mathrm{OR}=2.44)$ can be related to the development of hypospadias in the newborn'.

Regarding exposure to organochlorines, scholars ${ }^{16}$ conducted a case control study assessing the risk of hypospadias. The evaluation took place using the blood samples collected from the children to assess the levels of organochlorines and polymorphism in the CYP1A1, GSTM1 and GSTT1 genes. The results showed that exposure to high levels of organochlorines increased the risk of developing hypospadias ${ }^{16}$. In 2005 , Morera et al $^{14}$. conducted a case-control study, with 225 cases $(n=225)$ and 225 controls $(n=225)$, to assess exposure to pesticides during the prenatal period and the occurrence of hypospadias. Thus, they concluded that exposure to toxic agrochemicals increased the chances of developing hypospadias in the newborn $(\mathrm{OR}=1.54 ; \mathrm{Cl}=0.83-2.84)^{14}$. 
However, according to the other studies ${ }^{715}$, it was not possible to identify an association between exposure to toxic agrochemicals and the risk of hypospadias. Onde of the studies ${ }^{15}$ concluded that occupational exposure to fungicides, insecticides and herbicides in the maternal periconceptional period was not associated with an increased risk of hypospadias ( $\mathrm{OR}=0.78 ; 95 \% \mathrm{Cl}=0.61-1.01)$, while other authors ${ }^{7}$ showed no association between maternal exposure to toxic agrochemicals and hypospadias, as they found no statistically significant results when studying maternal exposure to brominated, polychlorinated biphenyls and other pesticides and the occurrence of hypospadias in their children.

In addition to this, in the case control study ${ }^{11}$, whose objective was to analyze maternal exposure in early pregnancy to organochlorines and an association with the risk of cryptorchidism, no statistically significant associations were found. As was the case in the cohort carried out by other authors ${ }^{10}$, where no association was also found between the use of this input and the occurrence of malformations related to the reproductive system.

\section{Malformations related to the nervous system}

Of the studies analyzed, seven ${ }^{18-24}$ showed an association between exposure to toxic agrochemicals and the occurrence of outcomes related to the Central Nervous System (CNS) in newborns. The association between maternal exposure to organochlorines and neural tube defects in newborns was verified through a case-control study. Blood levels of dichlorodiphenyldichlorethylene (DDE), total hexachlorocyclohexane $(\mathrm{t}-\mathrm{HCH})$ and endosulfan in mothers in the case group and in newborns with neural tube defects were significantly higher. Mothers who had children with NTDs were 11.3 times more likely to have DDE levels above the median concentration of the control group ${ }^{20}$.

In China, conducted a study ${ }^{22}$ to investigate the association between the occurrence of neural tube defects in newborns due to the exposure of pregnant women to toxic agrochemicals. The levels of agrochemicals were analyzed in placentas of pregnant women who had children with neural tube defects. Placental concentrations of polycyclic aromatic hydrocarbons (PAHs), organochlorine pesticides, polychlorinated biphenyls, dichlorodiphenyltrichloroethane (DDT) and hexachlorocyclohexane $(\mathrm{HCH})$ were significantly higher in the placentas with newborn NTD outcome. Thus, the risk for increased PAH levels was 4.52 times greater $(95 \% \mathrm{Cl}=2.10-9.74)$ for any neural tube defect, in addition to 5.84 $(95 \% \mathrm{Cl}=2.28-14.96)$ and 3.71 times $(95 \% \mathrm{Cl}=1.57-8.79)$ of increased risk of anencephaly and spina bifida, respectively ${ }^{22}$.

Authors ${ }^{21}$ analyzed the occurrence of NTDs in newborns of pregnant women who were exposed to toxic agrochemicals in the preconception and up to two months after conception. There was a positive, although not significant, association for the combined classes of insecticides and herbicides referring all types of NTDs. As for the joint classes of insecticides, herbicides and fungicides, there was a significant association for all NTD cases, with greater occurrence of anencephaly and encephalocele ${ }^{21}$.

In relation to other malformations related to the nervous system, an increased risk of newborns having anencephaly, spina bifida, cleft lip without or with cleft palate or cleft palate was identified in pregnant women with early exposition to toxic agrochemicals. The estimate was made based on residential proximity in places with application of agrochemicals. Petroleum derivatives contributed to the increase in the occurrence of anencephaly; herbicides, specifically hydroxybenzonitrile, for spina bifida; and 2,6-dinitroaniline herbicides and dithiocarbamate methyl isothiocyanate, for cleft lip or palate. However, none of the 26 chemical products analyzed had an Odds Ratios with an associated confidence interval, although this environmental factor may be a condition for the onset of these diseases ${ }^{23}$.

In a case-control study conducted in Mexico, authors ${ }^{18}$ evaluated the exposure of pregnant women to toxic agrochemicals and the emergence of defects in the neural tube of their newborns. 
According to the authors, interviews were conducted with the women for research on education, smoking and folate use. The women who used some chemical substance in their backyards were twice as likely to have newborns with neural tube defects $(95 \% \mathrm{Cl}=1.2-3.1)$ when compared to women without these reported exposures. In addition to this, the women in the case group also reported living less than $0.35 \mathrm{~km}$ from cultivated fields than women in the control group (OR=3.6;95\% $\mathrm{Cl}=1.7-7.6)$. Thus, the information regarding exposure to toxic agrochemicals increases the risk for the emergence of defects in the neural tube, especially of anencephaly in newborns ${ }^{50}$.

A study carried out in the USA identified an increased risk for the development of holoprosencephaly in children whose mothers were exposed to pesticides during the pre-conception period or during pregnancy $(\mathrm{OR}=2.60,95 \% \mathrm{Cl}=0.84-8.68)$. No association was found for occupational exposures to pesticides during pregnancy $(\mathrm{OR}=1.15,95 \% \mathrm{Cl}=0.11-11.42)^{19}$.

\section{Other malformations}

In addition to malformations related to the reproductive and nervous systems, articles were also found referring to malformations related to fetal growth restrictions $(n=2)^{27,31}$, to the digestive system $(n=3)^{29,32-33}$, to the musculoskeletal system $(n=1)^{26}$, to the circulatory system $(n=2)^{34,36}$, and congenital anomalies in general $(n=5)^{25,27,30,35,37}$.

In France in 2011, authors ${ }^{27}$ conducted a study between 2012 and 2016, using urinary biomarkers to detect exposure to atrazine before the $19^{\text {th }}$ gestational week and its possible adverse events for pregnancy. As a result, they found metabolites of this herbicide in between $20 \%$ and $40 \%$ of the samples, and the presence of these metabolites was positively associated with fetal growth restriction and small head circumference according to gender and gestational age ${ }^{27}$.

Also on fetal growth restriction, authors ${ }^{31}$ produced a study that sought to identify genes present in pregnant women with fetal growth restriction that interact with organochlorines, looking for the cause of the restriction. For this, the study used blood samples from the mother and the umbilical cord. Among these samples, significantly higher levels of organochlorines were found in the cases when compared to the controls ${ }^{31}$.

Regarding the digestive system, scholars ${ }^{33}$, conducted a case-control study to determine periconceptional exposure to toxic agrochemicals, finding an association between the development of gastroschisis and the distance of the maternal residence from places with high exposure to pesticides. As a result, gastroschisis was positively associated with those who lived $<25 \mathrm{~km}$ from places with high exposure $(\mathrm{OR}=1.6)$. However, authors ${ }^{32}$ verified that gastroschisis was also positively related to maternal occupational exposure to insecticides, herbicides and fungicides (OR=1.88; 95\% Cl). However, contrary to the results found by scholars others ${ }^{33}$, the study carried out in California ${ }^{32}$ did $^{2}$ not identify any association between exposure to triazines and gastroschisis or a standard profile related to women having children with gastroschisis.

The study carried out in the USA ${ }^{29}$, sought to identify the residential exposure of women to toxic agrochemicals and its relationship with choanal atresia or stenosis; it was found that the children of mothers with high exposure accordingly had an increase in choanal atresia or stenosis $(\mathrm{OR}=1.79 ; 95 \%$ $\mathrm{Cl})^{29}$. In relation to the occurrence of cleft palate and maternal occupational exposure to solvents and pesticides, a case-control study showed that maternal exposure to pesticides significantly increased the chance of developing cleft palate $(\mathrm{OR}=1.7 ; 95 \% \mathrm{Cl})^{37}$.

In Paraguay, a study ${ }^{30}$ sought to determine the association between the prenatal risk factors and the occurrence of congenital anomalies. An association was observed between malformations with distance $<1 \mathrm{~km}$ of the residence from fumigated fields $(\mathrm{OR}=3.75 ; 95 \% \mathrm{Cl}$ ) and direct maternal exposure to pesticides $(\mathrm{OR}=4.51 ; 95 \% \mathrm{Cl})^{30}$. 
In relation to congenital malformations in general, in a hospital in Mato Grosso do Sul, a Brazilian state that has agribusiness as the basis of its economy, one study ${ }^{38}$ investigated the association between parental exposure to pesticides and the occurrence of congenital malformations in children. Thus, a positive association was observed between exposure to toxic agrochemicals and the occurrence of congenital anomalies, associated with low maternal education $(\mathrm{OR}=8.40 ; 95 \% \mathrm{Cl})^{38}$. Another Brazilian study carried out in Mato Grosso do Sul ${ }^{25}$ sought to analyze the occurrence of congenital anomalies in the municipalities with the greatest exposure to toxic agrochemicals. Thus, significant associations were observed related to exposure to agrochemicals in the post-fertilization period (OR=1.66; $95 \%$ $\mathrm{Cl}$ and $\mathrm{OR}=1.88 ; 95 \% \mathrm{Cl})$ and in the periconceptional period $(\mathrm{OR}=2.04 ; 95 \% \mathrm{Cl})$.

In relation to paternal exposure to toxic agrochemicals and the occurrence of congenital anomalies, a case-control study ${ }^{28}$ analyzed that certain occupations during the periconceptional period can increase the chances of the occurrence of congenital anomalies. Parental occupation with pesticides, solvents, solder smoke, lead, working with video displays and computer monitors was studied, with a verified greater chance of having children with congenital anomalies in occupations with exposure to pesticides ( $\mathrm{OR}=3.42 ; 95 \% \mathrm{Cl}=1.97-5.92)$, solvents (OR=5.63, 95\% $\mathrm{Cl}=2.77-11.42$ ) and solder smoke (OR=2.98; $95 \% \mathrm{Cl}=0.99-8.54)$, in addition to inbreeding, which was considered a risk factor $(\mathrm{OR}=1.91,95 \% \mathrm{Cl}=1.25-2.92)^{28}$.

Regarding the malformations related to the circulatory system, a case-control study carried out in Hungary found a positive association between paternal exposure to pesticides (OR=1.66, 95\% $\mathrm{Cl}=1.03-2.69)$ and alkylphenolic compounds (OR=1.95, 95\% $\mathrm{Cl}=1.30-2.93)$ and the occurrence of patent ductus arteriosus. However, another case-control study, conducted in the Netherlands, found no association between maternal occupational exposure to pesticides and the occurrence of cardiac abnormalities ${ }^{34}$.

\section{Pesticides}

As for the toxic agrochemicals most frequently identified in the studies, it is worth mentioning that the Atrazine herbicide was the most reported $(n=11)^{8,17,21,24,26-27,29-30,33,36-37}$, followed by 11 studies that investigated organochlorines ${ }^{7,9-11,13,16,20-23,31}$.

The exposure to and/or application of toxic agrochemicals was verified in $(n=8)$ studies $^{14-15,25,28,30,37-38,52}$. Insecticides was examined in six studies $8,15,21,24,26,36$ and fungicides, in four studies $^{15,24,26,37}$. Only two studies investigated organophosphates ${ }^{21,32}$.

\section{DISCUSSION}

The toxic agrochemicals considered to be endocrine disruptors include insecticides, herbicides and fungicides. These inputs are used in agriculture, aquaculture and domestic uses, whose residues have been found in food, drinking water and water bodies ${ }^{43}$. Some classes of agrochemicals present estrogenic and/or anti-estrogenic activity, such as organochlorines and pyrethroids; and androgenic and/or antiandrogenic activity, such as organochlorines, organophosphates and atrazine. The endocrine disrupting toxic agrochemicals act by binding to specific steroid hormone receptors (estradiol, testosterone and progesterone), thus being able to inhibit or activate enzymes that act in the synthesis and metabolism of hormones, disrupting the function of the hypothalamus and pituitary ${ }^{44}$. 
Congenital malformations are the second leading cause of infant death in Latin America according to data from the World Health Organization ${ }^{45}$. A Brazilian study identified that the largest association found between the increase in the cryptorchidism malformation from the 1993-2004 period to the 2004-2014 period was in the state of Paraná. The researchers suggest that, for being endocrine disruptors, some toxic agrochemicals are suspected of influencing the sexual differentiation of the fetus and other sex hormone-dependent outcomes and that they can be related to the fluctuation of female and male hormones during pregnancy ${ }^{46}$.

In the USA, it was verified ${ }^{47}$ that women exposed to different classes of toxic agrochemicals obtained different levels of significant risk associated with the having children with hypospadias. A study $^{48}$ from Spain, on the other hand, evidenced that most of the agricultural workers studied had a high relative risk of fetal death due to congenital anomalies. In a case-control research study in the Netherlands ${ }^{49}$, paternal exposure to pesticides was significantly associated with cryptorchidism. A research study conducted in Paraguay ${ }^{9}$ found a relationship between congenital anomalies and exposure to toxic agrochemicals. A Brazilian study ${ }^{10}$ also found that maternal exposure to toxic agrochemicals during pregnancy was associated with congenital anomalies in the cities studied in the state of Mato Grosso, suggesting that populations intensely exposed to agrochemicals are at higher risk of fetal malformations.

In Mexico, a study ${ }^{13}$ evaluated mothers and children born with cryptorchidism and exposure to organochlorines and concluded that exposure to toxic agrochemicals was higher among the mothers with children who were born with cryptorchidism than among mothers of children with descended testicles. In a study ${ }^{30}$ carried out in Argentina, some risk factors for the emergence of congenital malformations were identified, among them distance of the house from the fumigated fields being less than $1 \mathrm{~km}(\mathrm{OR}=3.75 ; 95 \% \mathrm{Cl}=0.98-14.31)$ and direct maternal exposure to pesticides $(\mathrm{OR}=4.51$; $95 \% \mathrm{Cl}=1.77-11.46)$. This corroborates the articles ${ }^{18,23}$ which identified that homes close to crops and direct contact of pregnant women to toxic agrochemicals can cause neural tube defects and consequences for the nervous system.

In an ecological study conducted in Brazil, it was concluded that Brazilian states with high consumption of toxic agrochemicals presented an increase of $100 \%$ and $75 \%$, and that those with mean consumption, an increase of $65 \%$ and $23 \%$, respectively, in the risk of congenital anomalies in the CNS and in the Cardiovascular System at birth, when compared to low-use states ${ }^{51}$. Thus, it is reinforced that the environmental factors, especially exposure to toxic agrochemicals, can contribute to the emergence of congenital malformations related to the central nervous system, according to the articles ${ }^{18,20-21,23}$.

In this context, in a case-control study ${ }^{24}$ parental exposure to toxic agrochemicals and the onset of spina bifida in newborns were analyzed. The parents' joint occupational exposure to agrochemicals (herbicides, fungicides and insecticides) was positively associated with spina bifida (OR=1.5; 95\% $\mathrm{Cl}=0.9-2.4)$ when compared to the infants without parental exposure ${ }^{24}$. Among the articles of this study, herbicides were the most reported for the occurrence of congenital malformations together with insecticides and fungicides, not only for neural tube defects ${ }^{21,23}$, but also for other malformations such as those related to the reproductive system and to the gastrointestinal tract ${ }^{15,26}$.

Corroborating the findings of this study, a systematic review ${ }^{53}$ that sought to identify the risk factors related to maternal exposure and congenital malformations found similar results, as well as higher prevalence of cardiovascular, gastrointestinal, genitourinary, musculoskeletal and nervous system malformations ${ }^{53}$. Regarding the results found related to gastroschisis, a study carried out in the USA identified the prevalence of this malformation in cases coming from places with excessive use of pesticides for restricted use. In addition, a study ${ }^{54}$ carried out in Campinas, São Paulo, also linked exposure to toxic agrochemicals during pregnancy with the occurrence of gastroschisis. 
In a Brazilian study ${ }^{55}$ carried out between 2004 and 2006 in Nova Friburgo, state of Rio de Janeiro, higher prevalence of congenital malformations, low birth weight and low Apgar score in newborns in rural areas of the city were identified. The study also highlighted the occurrence of cleft palate as the third most prevalent outcome ${ }^{55}$.

The occurrence of congenital anomalies related to exposure to pesticides was also reported in a study conducted in South Africa. Through a control case study, it was concluded that newborns from mothers exposed to toxic agrochemicals were seven times more likely to develop some congenital anomaly when compared to newborns from mothers who did not suffer exposure ${ }^{56}$.

Among the agrochemicals most used in articles analyzed in a systematic review study, atrazine, methyl bromide, cyanazine, DDT, dicamba, DDE and HCB were found ${ }^{53}$. Atrazine is one of the most widely used agricultural herbicides in the last 50 years in the United States of America and, in Brazil, it was the fourth most commercialized active ingredient in $2018^{17,57}$. Among the effects on health are dysregulation of the endocrine system, cardiovascular diseases and genitourinary malformations ${ }^{17,58}$.

It is also worth mentioning some limitations of this study, such as the language of the search and inclusion strategies, since studies published in other languages and in other databases may not have been included using the strategy presented. Therefore, the impact of cultural diversity may suffer from this limitation. The authors acknowledge that important studies may have been omitted.

\section{CONCLUSION}

The implications of this study for the practice can be seen in the sense of strengthening the evidence related to the association between exposure to toxic agrochemicals and congenital malformations. With this review, it was concluded that maternal and paternal exposure to agrochemicals can be associated with greater chances of children being born with congenital malformations, especially those related to the male reproductive system.

A gap identified by the study is the low number of relevant papers published worldwide, mainly by the USA, Brazil and China, which are the main consumers of toxic agrochemicals. It is believed that this study will contribute to giving visibility to the theme and, thus, collaborate in the prevention of the population's exposure to toxic agrochemicals and in the birth of children with congenital malformations. In addition to this, it will contribute to the prevention and tracking of congenital anomalies during Nursing care, mainly during prenatal care through Nursing consultations in Primary Health Care.

\section{REFERENCES}

1. Ueker ME, Silva VM, Moi GP, Pignati WA, Mattos IE, Silva AMC. Parenteral exposure to pesticides and occurence of congenital malformations: hospital-based case-control study. BMC Pediatr [Internet]. 2016 [cited 2020 Jul 06];16(1):125. Available from: https://doi.org/10.1186/s12887016-0667-x

2. Foster WG, Evans JA, Little J, Arbour L, Moore A, Sauve R. Human exposure to environmental contaminants and congenital anomalies: a critical review. Crit Rev Toxicol [Internet]. 2017 [cited 2020 Jul 06];47(1):59-84. Available from: https://doi.org/10.1080/10408444.2016.1211090

3. World Health Organization. Congenital anomalies, 2016. Geneva (CH): WHO, 2016 [cited 2020 Jul 06]. Available from: https://www.who.int/news-room/fact-sheets/detail/congenitalanomalies

4. Carneiro FF, Rigotto RM, Augusto LGS, Friedrich K, Búrigo AC. Dossiê ABRASCO: um alerta sobre os impactos dos agrotóxicos na saúde. Rio de Janeiro, RJ(BR): EPSJV; São Paulo, SP(BR): Expressão Popular, 2015 [cited 2020 Jul 06]. Available from: https://www.abrasco.org. br/dossieagrotoxicos/wp-content/uploads/2013/10/dossieabrasco_2015_web.pdf 
5. Pignati WA, Lima FANS, Lara SS, Correa MLM, Barbosa JR, Leão LHC, et al. Distribuição espacial do uso de agrotóxicos no Brasil: uma ferramenta para a Vigilância em Saúde. Ciênc Saúde Coletiva [Internet]. 2017 [cited 2020 Jul 06];22(10):3281-93. Available from: https://doi. org/10.1590/1413-812320172210.17742017

6. Melnyk BM, Fineout-Overholt E. Making the case for evidence-based practice. In: Melnyk BM, Fineout-Overholt E. Evidence-based practice in Nursing \& Healthcare. A guide to best practice. 3rd ed. Philadelphia(US): Lippincot Williams \& Wilkins; 2014.

7. Carmichael SL, Herring AH, Sjödin A, Jones R, Larry N, Ma C, et al. Hypospadias and halogenated organic pollutant levels in maternal mid-pregnancy serum samples. Chemosphere [Internet]. 2010 [cited 2020 Jul 06]; 80(6):641-6. Available from: https://doi.org/10.1016/j.chemosphere.2010.04.055

8. Gaspari L, Sampaio DR, Paris F, Audran F, Orsini M, Neto JB, Sultan C. High prevalence of micropenis in 2710 male newborns from na intensive-use pesticide area of Northeastern Brazil. Int J Androl [Internet]. 2012 [cited 2020 Jul 6];35(3):253-64. Available from: https://doi. org/10.1111/j.1365-2605.2011.01241.x

9. Giordano F, Abballe A, De Felip E, di Domenico A, Ferro F, Grammatico P et al. Maternal exposures to endocrine disrupting chemicals and hypospadias in offspring. Birth Defects Res A Clin Mol Teratol [Internet] 2010 [cited 2020 Jul 6];88(4):241-50. Available from: https://doi. org/10.1002/bdra.20657

10. Rouget F, Kadhel P, Monfort C, Viel JF, Thome JP, Cordier S, et al. Chlordecone exposure and risk of congenital anomalies: the Timoun Mother-Child Cohort Study in Guadeloupe (French West Indies). Environ Sci Pollut Res Int [Internet]. 2020 Nov [cited 2020 Jul 06];27(33):40992-8. Available from: https://doi.org/10.1007/s11356-019-06031-y

11. Axelsson J, Scott K, Dillner J, Lindh $\mathrm{CH}$, Zhang $\mathrm{H}$, Rylander L, et al. Exposure to polychlorinated compounds and cryptorchidism; A nested case-control study. PLoS One [Internet]. 2020 Jul 23 [cited 2020 Dec 08];15(7):e0236394. Available from: https://doi.org/10.1371/journal.pone.0236394

12. Michalakis M, Tzatzarakis MN, Kovatsi L, Alegakis KA, Tsakalof AK, Heretise I, et al. Hypospadias in offspring is associated with chronic exposure of parents to organophosphate and organochlorine pesticides. Toxicol Lett [Internet] 2014 [cited 2020 Jul 06];230(2):139-45. Available from : https:// doi.org/10.1016/j.toxlet.2013.10.015

13. Montes LPB, Waliszewskill S, Hernández-Valerolll M, Sanín-Aguirre L, Infanzón-Ruiz R, Jañas AG. Exposición prenatal a los plaguicidas organoclorados y criptorquidia. Ciênc Saúde Coletiva [Internet]. 2010 [cited 2020 Jul 06];15(Suppl 1):1169-74. Available from: https://doi.org/10.1590/ S1413-81232010000700025

14. Morera AM, Valmalle AF, Asensio MJ, Chauvin MA, Durand P. A study of risk factors for hypospadias in the Rhône-Alpes region (France). J Pediatr Urol [Internet] 2006 [cited 2020 Jul 06];2(3):16977. Available from: https://doi.org/10.1016/j.jpurol.2005.09.008

15. Rocheleau CM, Romitti PA, Sanderson WT, Sun L, Lawson CC, Waters MA, et al. Maternal occupational pesticide exposure and risk of hypospadias in the National birth defects prevention study. Birth Defects Res A Clin Mol Teratol [Internet]. 2011 [cited 2020 Jul 06];91(11):927-36. Available from: https://doi.org/10.1002/bdra.22860

16. ShekharYadav C, Bajpai M, Kumar V, Ahmed RS, Gupta P, Banerjee BD. Polymorphism in CYP1A1, GSTMI, GSTT1 genes and organochlorine pesticides in the etiology of hypospadias. Hum Exp Toxicol [Internet] 2011 [cited 2020 Jul 06];30(10):1464-74. Available from: https://doi. org/10.1177/0960327110392402 
17. Winston JJ, Emch M, Meyer RE, Langlois P, Weyer P, Mosley B, et al. Hypospadias and maternal exposure to atrazine via drinking water in the National Birth Defects Prevention study. Environ Health [Internet]. 2016 [cited 2020 Jul 06];15(1):76. Available from: https://doi.org/10.1186/ s12940-016-0161-9

18. Brender JD, Felkner M, Suarez L, Canfield MA, Henry JP. Maternal pesticide exposure and neural tube defects in Mexican Americans. Ann Epidemiol. [Internet]. 2010 [cited 2020 Jul 06];20(1):1622. Available from: https://doi.org/10.1016/j.annepidem.2009.09.011

19. Addissie YA, Kruszka P, Troia A, Wong ZC, Everson JL, Kozel BA, et al. Prenatal exposure to pesticides and risk for holoprosencephaly: a case control study. Environ Health [Internet]. 2020 [cited 2020 Dec 08];19(1):65. Available from: https://doi.org/10.1186/s12940-020-00611-z

20. Kalra S, Dewan P, Batra P, Sharma T, Tyagi V, Banerjee BD. Organochlorine pesticide exposure in mothers and neural tube defects in offsprings. Reprod Toxicol [Internet]. 2016 [cited $2020 \mathrm{Jul}$ 06];66:56-60. Available from: https://doi.org/10.1016/j.reprotox.2016.09.005

21. Makelarski JA, Romitti PA, Rocheleau CM, Burns TL, Stewart PA, Waters MA, et al. Maternal periconceptional occupational pesticide exposure and neural tube defects. Birth Defects Res A Clin Mol Teratol [Internet]. 2014 [cited 2020 Jul 06];100(11):877-86. Available from: https://doi. org/10.1002/bdra.23293

22. Ren A, Qiu X, Jin L, Ma J, Zhiwen L, Zhang L, et al. Association of selected persistent organic pollutants in the placenta with the risk of neural tube defects. Proc Natl Acad Sci USA [Internet]. 2011 [cited 2020 Jul 06];108(31):12770-5. Available from: https://doi.org/10.1073/pnas.1105209108

23. Yang W, Carmichael SL, Roberts EM, Kegley SE, Padula AM, English PB, et al. Residential agricultural pesticide exposures and risk of neural tube defects and orofacial clefts among offspring in the San Joaquin Valley of California. Am J Epidemiol [Internet]. 2014 [cited 2020 Jul 06];179(6):740-8. Available from: https://doi.org/10.1093/aje/kwt324

24. Pettigrew SM, Bell EM, Van Zutphen AR, Rocheleau CM, Shaw GM, Romitti PA, et al. Paternal and joint parental occupational pesticide exposure and spina bifida in the National Birth Defects Prevention Study, 1997 to 2002. Birth Defects Res A Clin Mol Teratol [Internet]. 2016 [cited 2020 Jul 06];106(11):963-71. Available from: https://doi.org/10.1002/bdra.23551

25. Oliveira NP, Moi GP, Atanaka-Santos M, Silva AMC, Pignati WA. Malformações congênitas em municípios de grande utilização de agrotóxicos em Mato Grosso, Brasil. Ciênc Saúde Coletiva [Internet]. 2014 [cited 2020 Jul 06];19(10):4123-30. Available from: https://doi.org/10.1590/1413812320141910.08512014

26. Kielb C, Lin S, Herdt-Losavio M, Bell E, Chapman B, Rocheleau CM, et al. Maternal periconceptional occupational exposure to pesticides and selected musculoskeletal birth defects. Int J Hyg Environ Health [Internet] 2014 [cited 2020 Jul 06];217(2-3):248-54. Available from: https://doi. org/10.1016/j.ijheh.2013.06.003

27. Chevrier C, Limon G, Monfort C, Rouget F, Garlantézec R, Petit C, et al. Urinary biomarkers of prenatal atrazine exposure and adverse birth outcomes in the PELAGIE birth cohort. Environ Health Perspect [Internet]. 2011 [cited 2020 Jul 03];119(7):1034-41. Available from: https://doi. org/doi:10.1289/ehp.1002775

28. El-Helaly M, Abdel-Elah K, Haussein A, Shalaby H. Paternal occupational exposures and the risk of congenital malformations--a case-control study. Int J Occup Med Environ Health [Internet] 2011 [cited 2020 Jul 06];24(2):218-27. Available from: https://doi.org/10.2478/s13382-011-0019-x

29. Agopian AJ, Cai Y, Langlois PH, Canfield MA, Lupo PJ. Maternal residential atrazine exposure and risk for choanal atresia and stenosis in offspring. J Pediatr [Internet]. 2013 [cited 2020 Jul 6];162(3):581-6. Available from: https://doi.org/10.1016/j.jpeds.2012.08.012 
30. Ojeda CL, Leite SB. Factores de riesgo prenatales y su asociación a malformaciones congénitas en un hospital universitario de referência. Pediatr (Asunción) [Internet]. 2018 [cited 2020 Jul 06];45(1):8-16. Available from: https://doi.org/10.31698/ped.45012018002

31. Sharma E, Mustafa M, Pathak R, Ahmed RS, Vaid NB, Baneriee BD. A case control study of gene environmental interaction in fetal growth restriction with special reference to organochlorine pesticides. Eur J Obstet Gynecol Reprod Biol [Internet]. 2012 [cited 2020 Jul 06];161(2):163-9. Available from: https://doi.org/10.1016/j.ejogrb.2012.01.008

32. Shaw GM, Yang W, Roberts E, Kegley SE, Padula A, English PB, Carmichael SL. Early pregnancy agricultural pesticide exposures and risk of gastroschisis among offspring in the San Joaquin Valley of California. Birth Defects Res A Clin Mol Teratol [Internet]. 2014 [cited 2020 Jul 06];100(9):68694. Available from: https://doi.org/10.1002/bdra.23263

33. Waller SA, Paul K, Peterson SE, Hitti JE. Agricultural-related chemical exposures, season of conception, and risk of gastroschisis in Washington State. Am J Obstet Gynecol [Internet]. 2010 [cited 2020 Jul 06];202(3):p241.e1-241.e6. Available from: https://doi.org/10.1016/j. ajog.2010.01.023

34. Fazekas-Pongor V, Csáky-Szunyogh M, Fekete M, Mészáros A, Cseh K, Pénzes M. Congenital heart diseases and parental occupational exposure in a Hungarian case-control study in 1997 to 2002. Congenit Anom (Kyoto) [Internet]. 2021 Mar [cited 2020 Dec 04];61(2):55-62. Available from: Available from: https://doi.org/10.1111/cga.12401.

35. Mekonnen AG, Hordofa AG, Kitila TT, Sav A. Modifiable risk factors of congenital malformations in bale zone hospitals, Southeast Ethiopia: an unmatched case-control study. BMC Pregnancy Childbirth [Internet]. 2020 [cited 2020 Dec 04];20(1):129. Available from: https://doi.org/10.1186/ s12884-020-2827-0

36. Spinder N, Bergman JEH, Kromhout H, Vermeulen R, Corsten-Janssen N, Boezen HM, et al. Maternal occupational exposure and congenital heart defects in offspring. Scand J Work Environ Health [Internet]. 2020 [cited 2020 Dec 4];46(6):588-608. Available from: https://doi.org/10.5271/ sjweh.3912

37. Spinder N, Bergman JE, Boezen HM, Vermeulen RC, Kromhout H, Walle HE. Maternal occupational exposure and oral clefts in offspring. Environ Health [Internet] 2017 [cited 2020 Jul 06]; 16:83. Available from: https://doi.org/10.1186/s12940-017-0294-5

38. Ueker ME, Silva VM, Moi GP, Pignati WA, Mattos IE, Silva AMC. Parenteral exposure to pesticides and occurence of congenital malformations: hospital-based case-control study. BMC Pediatr [Internet]. 2016 [cited 2020 Jul 06];16(1):125. Available from: https://doi.org/10.1186/s12887016-0667-x

39. Joanna Briggs Institute. Reviewer's manual: 2015 edition/supplement. The University of Adelaide, Austrália: JBI [Internet]. 2015 [cited 2020 Jul 6]. Available from: https://nursing.Isuhsc.edu/JBI/ docs/ReviewersManuals/Scoping-.pdf

40. Arksey H, O'Malley L. Scoping studies: Towards a methodological framework. Int J Soc Res Methodol [Internet]. 2005 [cited 2020 Jul 3];8(1):19-32. Available from: https://doi. org/10.1080/1364557032000119616

41. Levac D, Colquhoun H, O'Brien KK. Scoping studies: advancing the methodology. Implemen Sci [Internet]. 2010 [cited $2020 \mathrm{Jul}$ 3];5(69):2-9. Available from: https://doi.org/10.1186/1748-5908-5-69

42. PRISMA. Extension for Scoping Reviews (PRISMA-ScR): checklist and explanation. Ann Intern Med [Internet]. 2018 [cited 2020 Jul 3];169(7):467-73. Available from: https://www.ncbi.nlm.nih. gov/pubmed/30178033 
43. Guimarães RM. Exposição a organoclorados e alterações em caracteres sexuais primários e secundários na população exposta em Cidade dos Meninos [tese]. Rio de Janeiro: Universidade Federal do Rio de Janeiro, Instituto de Estudos em Saúde Coletiva; 2011 [cited 2020 Jul 06]. Available from: http://www.posgraduacao.iesc.ufrj.br/media/tese/1368466441.pdf

44. Dutra LS. Malformações congênitas e exposição a agrotóxicos disruptores endócrinos em estados brasileiros [tese]. Rio de Janeiro, RJ(BR): Escola Nacional de Saúde Pública Sergio Arouca, Fundação Oswaldo Cruz; 2019 [cited 2020 Jul 06]. Available from: https://www.arca. fiocruz.br/bitstream/icict/33993/2/ve_Lidiane_Silva_ENSP_2019.pdf

45. Organização Pan-Americana da Saúde (OPAS). Registros de defeitos congênitos estão em expansão na América Latina. [Internet] 2019 [cited 2020 June 14]. Available from: https://www.paho. org/bra/index.php?option=com_content\&view=article\&id=6005:registros-dedefeitoscongenitosesta oemexpansaonaamericalatina\&itemid=820\#: :text=os $\% 20$ defeitos $\% 20$ cong $\%$ c3\%aanitos $\% 20$ s\%c3\%a3o\%20a,0\%20\%c3\%b4nus\%20real\%20dessas\%20condi\%c3\%a7\%c3\%b5es

46. Dutra LS, Ferreira AP. Associação entre malformações congênitas e a utilização de agrotóxicos em monoculturas no Paraná, Brasil. Saúde em Debate [Internet]. 2017 [cited 2020 Jun 14];41(Spe):24153. Available from: https://doi.org/10.1590/0103-11042017S220

47. Meyer KJ, Reif JS, Veeramachaneni DN, Luben TJ, Mosley BS, Nuckols JR. Agricultural pesticide use and hypospadias in eastern Arkansas. Environ Health Perspect [Internet] 2006 [cited 2020 Jul 6];114(10):1589-95. Available from: https://doi.org/10.1289/ehp.9146

48. Regidor E, Ronda E, García AM, Dominguez V. Paternal exposure to agricultural pesticides and cause specific fetal death. Occup Environ Med [Internet] 2004 [cited 2020 Jul 6];61:334-9. Available from: https://doi.org/10.1136/oem.2003.009043

49. Pierink FH, Burdorf A, Deddens JA, Juttmann ER, Weber RFA. Maternal and paternal risk factors for cryptorchidism and hypospadias: a case-control study in newborn boys. Environ Health Perspect [Internet]. 2014 [cited 2020 Jul 6];112(15):1570-6. Available from: https://doi. org/10.1289/ehp.7243

50. Brender JD, Felkner M, Suarez L, Canfield MA, Henry JP. Maternal pesticide exposure and neural tube defects in Mexican Americans. Ann Epidemiol. [Internet]. 2010 [cited 2020 Jul 06];20(1):1622. Available from: https://doi.org/10.1016/j.annepidem.2009.09.011

51. Froes Asmus CIR, Camara VM, Raggio R, Landrigan PJ, Claudio L. Positive correlation between pesticide sales and central nervous system and cardiovascular congenital abnormalities in Brazil. Int J Environ Health Res [Internet]. 2017 [cited 2020 June 14];27(5):420-6. Available from: https:// doi.org/10.1080/09603123.2017.1373272

52. Brender JD, Felkner M, Suarez L, Canfield MA, Henry JP. Maternal pesticide exposure and neural tube defects in Mexican Americans. Ann Epidemiol [Internet]. 2010 [cited 2020 Jul 06];20(1):1622. Available from: https://doi.org/10.1016/j.annepidem.2009.09.011

53. Matos VGF. Exposição materna aos agrotóxicos e a ocorrência de malformações congênitas: uma revisão sistemática [dissertação]. Cuiabá: Universidade de Cuiabá. Programa de Pós-graduação em Meio Ambiente; 2019 [cited 2020 June 14]. Available from: https://repositorio.pgsskroton. com.br/bitstream/123456789/23807/1/vanessa\%20gama\%0freitas\%20de\%20matos.pdf

54. Barbieri MM. Padrão de crescimento em fetos com gastrosquise: valores de referêcia para parâmetros ultrassonográficos e dopplervelocimetria das artérias umbilicais [dissertação]. Campinas: Universidade Estadual de Campinas, Faculdade de Ciências Médicas, Programa de Pós-Graduação em Tocoginecologia; 2017 [cited 2020 June 14]. Available from: http://repositorio. unicamp.br/bitstream/REPOSIP/325002/1/Barbieri_MarianeMassaini_M.pdf 
55. Chrisman JR, Mattos IE, Koifman RJ, Koifman S, Baccolini PMM, Meyer A. Prevalence of very low birthweight, malformation, and low apgar score among newborns in Brazil according to maternal urban or rural residence at birth. J Obstet Gynaecol Res [Internet]. 2016 [cited 2020 Jun 14];42(5):496-504. Available from: https://doi.org/10.1111/jog.12946

56. Heeren GA, Tyler J, Mandeya A. Agricultural chemical exposures and birth defects in the eastern cape province, south africa a case-control study. Environ Health [Internet]. 2003 [cited 2020 June 14];2:11. Available from: https://doi.org/10.1186/1476-069X-2-11

57. Ministério do Meio Ambiente (BR). Instituto Brasileiro do Meio Ambiente e dos Recursos Naturais Renováveis. Relatórios de comercialização de agrotóxicos. Brasília, DF(BR): Ministério do Meio Ambiente. [Internet] 2018 [cited 2020 Feb 12]. Available from: http://www.ibama.gov.br/ agrotoxicos/relatoriosdecomercializacaodeaggrotoxicos\#sobreosrelatorios

58. Chan YC, Chang SC, Hsuan SL, Chien MS, Lee WC, Kang JJ, et al. Cardiovascular effects of herbicides and formulated adjuvants on isolated rat aorta and heart. Toxicol in Vitro [Internet], 2007 [cited 2019 May 5];21(4):595-603. Available from: https://doi.org/10.1016/j.tiv.2006.12.007 


\section{NOTES}

\section{CONTRIBUTION OF AUTHORITY}

Study design: Costa NZ, Riquinho DL, Dalla Nora CR, Souto LHD, Carlotto FD, Afonso RS.

Data collection: Costa NZ, Riquinho DL, Dalla Nora CR, Souto LHD, Carlotto FD.

Data analysis and interpretation: Costa NZ, Riquinho DL, Dalla Nora CR, Souto LHD, Carlotto FD.

Discussion of the results: Costa NZ, Riquinho DL, Dalla Nora CR, Souto LHD, Carlotto FD.

Writing and/or critical review of the content: Costa NZ, Riquinho DL, Dalla Nora CR, Souto LHD, Carlotto FD.

Review and final approval of the final version: Costa NZ, Riquinho DL, Dalla Nora CR, Souto LHD, Carlotto FD.

\section{FUNDING INFORMATION}

Granted with resources from Universal Call MCTIC/CNPq No. 28/2018.

\section{CONFLICT OF INTEREST}

There is no conflict of interest.

\section{EDITORS}

Associated Editors: Mara Ambrosina de Oliveira Vargas, Gisele Cristina Manfrini, Ana Izabel Jatobá de Souza.

Editor-in-chief: Roberta Costa.

\section{HISTORICAL}

Received: Sepember 16, 2020.

Approved: December 17, 2020.

\section{CORRESPONDING AUTHOR}

Nathalia Zorzo Costa

nzorzo@gmail.com 